\title{
Enantioselective 4-Hydroxylation of Phenols under Chiral Organoiodine(I/III) Catalysis
}

\author{
Kilian Muñiz*a,b \\ Laura Fra ${ }^{a}$ \\ a Institute of Chemical Research of Catalonia (ICIQ), The \\ Barcelona Institute of Science and Technology, Av. Països \\ Catalans 16, 43007 Tarragona, Spain \\ b ICREA, Pg. Lluís Companys 23, 08010 Barcelona, Spain \\ kmuniz@iciq.es
}<smiles>[R]c1ccc(O)c([X])c1</smiles>

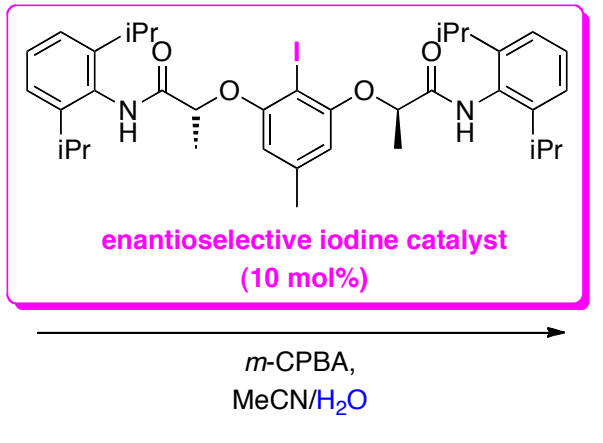

Hydroxylated products (10 examples, up to $50 \%$ ee)

\begin{abstract}
Received:
Accepted:

DOI:

Abstract A procedure for the intermolecular enantioselective dearomatization of phenols under chiral (I/III) catalysis is reported. This protocol employs $m C P B A$ as the terminal oxidant together with a defined $\mathrm{C}_{2}$-symmetric aryl iodide as the effective organocatalyst. This enantioselective reaction proceeds with complete selectivity under mild conditions and enables the hydroxylative dearomatization of a number of phenols into the corresponding para-quinol products with up to $50 \%$ ee.

Key words Catalysis, Chirality, Dearomatization, Hydroxylation, Hypervalent Iodine, Oxidation.
\end{abstract}

Hypervalent iodine reagents have emerged as popular reagents for organic synthesis. ${ }^{1}$ Traditionally employed in the form of stoichiometric reagents, recent accomplishments have provided effective solutions for their use as selective catalysts in oxidation reactions. ${ }^{2}$ Thus, iodine(III) chemistry has reached an economically and ecologically relevant level and now starts to rival catalysis with transition metals.

A reaction that is particularly linked to iodine(III) chemistry is the oxidative dearomatization of phenols. ${ }^{3}$ This reaction shows a synthetically interesting scope and can be conducted for various hydroxyl-substituted arenes. It makes use of the readily accessible coordination of the iodine(III) to the $\mathrm{OH}$ group of the substrate. From this initial step of phenol oxidation with the iodine(III), oxocyclopentadienyl cations are formed as intermediates, which subsequently add nucleophiles in an overall process that constitutes an umpolung of the inherent phenol reactivity (Scheme 1). Alternatively, a simultaneous addition of the nucleophile to the coordinated phenolate has been put forward as the reaction mechanism. A seminal accomplishment by Yakura and Konishi disclosed the development of reaction conditions that allow working with catalytic amounts of iodine(III) reagents. ${ }^{4}$
Usually, 1,4-oxidation to the deconjugated product is preferred with iodine(III) catalysts. ${ }^{4}$ Impressive selectivity for 1,2oxidations has been developed recently for an iodine(V) catalyst. ${ }^{5}$ In addition, 1,2-dione formation was accomplished under related iodine $(\mathrm{V})$ catalysis. $^{6}$

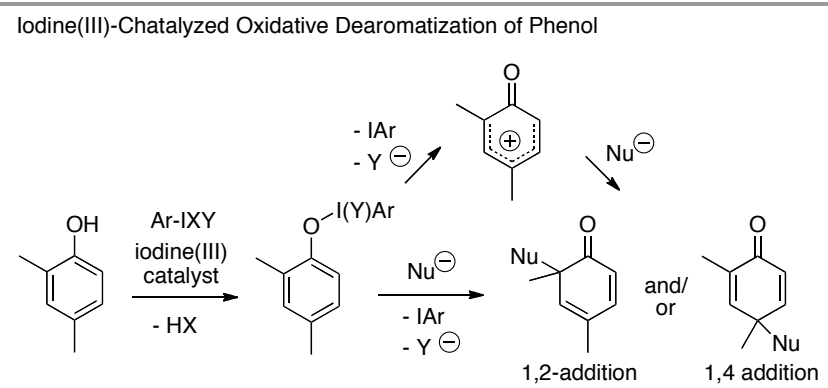

Harned (2013, ref. 10)
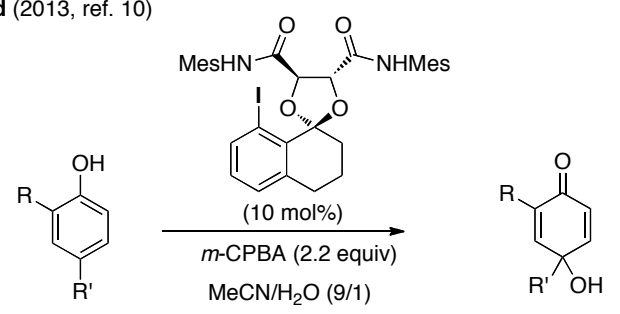

up to $60 \%$ ee

Scheme 1 Pathways for the intermolecular dearomatization reaction of phenol under iodine(III) catalysis and enantioselective variant.

An important aspect addresses the development of reactions that proceed under catalyst enantiocontrol.7 Such a process is of obvious challenge as the differentiation of the enantiotopic faces can only be accomplished if the chiral catalyst remains attached to the phenol substrate (Scheme 1). ${ }^{8}$ Within this context, Quideau has pioneered the enantioselective catalytic 2- 
hydroxylation of phenols and naphthols. ${ }^{9}$ In a subsequent development, Harned reported the use of a tartaric acid derived chiral iodine for the 4-hydroxylation of phenols (Scheme 1, below). ${ }^{10}$ This reaction constitutes the so far only example of an enantioselective 4-hydroxylation of phenols under iodine(III) catalysis (up to $60 \%$ ee).

In its intramolecular fashion, the reaction is generally known as Kita oxidation, ${ }^{3,11}$ for which suitable nucleophilic groups are preinstalled in the substrate. Also in these cases, reaction conditions have been developed to perform enantioselective catalytic transformations. ${ }^{12,13}$ The Kita oxidation has become an attractive tool for the effective preparation of building blocks in total synthesis. ${ }^{14}$

These accomplishments demonstrate the importance of enantioselective iodine catalysis for the particular case of phenol dearomatization.

We recently contributed to the field of enantioselective iodine(III) catalysis with the development of monomeric catalysts for the difunctionalization of alkenes under intermolecular reaction control.15,16 Within the course of this investigation, we aimed to broaden the scope of these compounds. Interested in the possible applicability of these catalysts in related intermolecular enantioselective oxidations, we decided to explore the hydroxylation of phenols.

Our investigation started with an exploration of a suitable iodine(I) catalyst motif. Harned had already explored the parent Ishihara catalyst 1, which provided low enantioinduction $(25 \%$ ee). ${ }^{10}$ We speculated that bulkier amide groups should have a positive influence on the enantioselection of the dearomatization reaction.

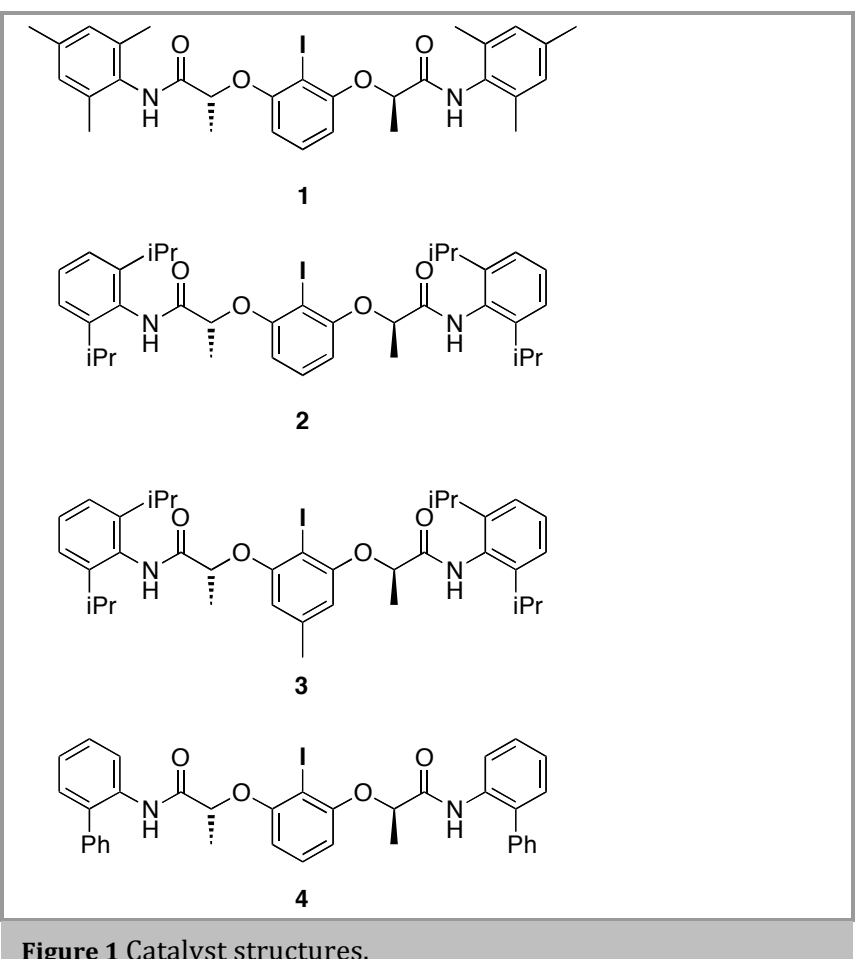

Figure 1 Catalyst structures.

To this end, we employed the recently reported iodine(I) compounds $\mathbf{2}$ and $\mathbf{3}$ and prepared a new derivative $\mathbf{4}$ with an extended 2-phenyl substitution pattern in the amide group
(Figure 1). The dearomatization of 2,4-dimethyl phenol 5a was chosen for the screening of reaction conditions (Table 1). Use of $10 \mathrm{~mol} \%$ of iodine(I) 2 as catalyst source together with 2.2 equivalents of $m C$ PBA as terminal oxidant at room temperature yielded the dearomatized product $\mathbf{6 a} 27 \%$ isolated yield and $32 \%$ ee (entry 1). This result directly represents the highest enantiomeric excess obtained so far for this substrate. ${ }^{10}$ Subsequent increase inthe catalyst loading provided an enhanced yield, while the ee remained unchanged (entries 2,3). Related results were obtained with catalysts $\mathbf{3}$ and $\mathbf{4}$, although some interesting increases in yield could be observed (entries 46). At lower temperature, the enantioselectivities increased for all three catalysts (entries 7-9), although 4 performed slightly less effective. At a reaction temperature of $-5{ }^{\circ} \mathrm{C}$, the kinetic performance of $\mathbf{3}$ was significantly better than that of $\mathbf{2}$ (entries 10,11 ), which is in agreement with a faster reoxidation of $\mathbf{3}$ due to the 4-methyl substituent at the central arene core.15a With $\mathbf{3}$ as catalyst, subsequent optimization revealed that an increase in catalyst loading or successive addition of the oxidant did not affect the reaction outcome (entries 12-13). Changing the amounts of terminal oxidant did not provide major changes as did the a change in solvent composition (entries 14-19). Finally, with 1.8 equivalents of $m$ CPBA a result closely related to the conditions from entry 11 could be accomplished (entry 20).

Table 1 Optimization of the catalytic enantioselective hydroxylation of phenol 5 a.

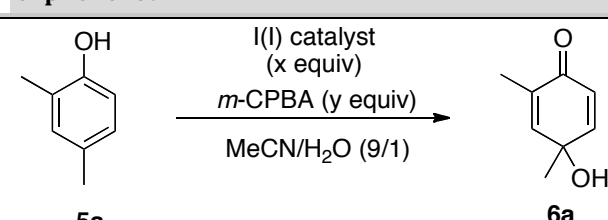

\begin{tabular}{|c|c|c|c|c|c|c|}
\hline Entry & $\begin{array}{l}\text { Iodine } \\
\text { Cat. }\end{array}$ & $x$ & $\mathrm{y}$ & $\mathrm{T}\left[{ }^{\circ} \mathrm{C}\right]$ & $\begin{array}{l}\text { Yield } \\
{[\%]} \\
\text { [a] }\end{array}$ & $\begin{array}{l}E e \\
{[\%]^{[b]}}\end{array}$ \\
\hline 1 & 2 & 0.1 & 2.2 & 24 & 27 & 32 \\
\hline 2 & 2 & 0.15 & 2.2 & 24 & 51 & 30 \\
\hline 3 & 2 & 0.2 & 2.2 & 24 & 62 & 28 \\
\hline 4 & 3 & 0.1 & 2.2 & 24 & 33 & 26 \\
\hline 5 & 3 & 0.15 & 2.2 & 24 & 76 & 28 \\
\hline 6 & 4 & 0.1 & 2.2 & 24 & 53. & 25 \\
\hline 7 & 2 & 0.1 & 2.2 & 0 & 49 & 45 \\
\hline 8 & 3 & 0.1 & 2.2 & 0 & 44 & 44 \\
\hline 9 & 4 & 0.1 & 2.2 & 0 & 45 & 38 \\
\hline 10 & 2 & 0.1 & 2.2 & -5 & 54 & 50 \\
\hline 11 & 3 & 0.1 & 2.2 & -5 & 96 & 50 \\
\hline 12 & 3 & 0.15 & 2.2 & -5 & 98 & 50 \\
\hline $13[c]$ & 3 & 0.1 & 2.2 & -5 & 97 & 48 \\
\hline 14 & 3 & 0.1 & 1.5 & -5 & 90 & 48 \\
\hline 15 & 3 & 0.1 & 3 & -5 & 87 & 48 \\
\hline $16^{[\mathrm{d}]}$ & 3 & 0.1 & 2.2 & -5 & 52 & 46 \\
\hline 17 [e] & 3 & 0.1 & 2.2 & -5 & 67 & 48 \\
\hline $18^{[\mathrm{f}]}$ & 3 & 0.1 & 2.2 & -5 & 84 & 44 \\
\hline $19[\mathrm{f}]$ & 3 & 0.1 & 1.5 & -5 & 83 & 46 \\
\hline $20[f]$ & 3 & 0.1 & 1.8 & -5 & 94 & 46 \\
\hline
\end{tabular}

a Isolated yield after purification. ${ }^{b}$ Determined by chiral HPLC analysis (XXX). c The oxidant was added in two portions. d $2: 1 \mathrm{MeCN}: \mathrm{H}_{2} \mathrm{O}$ was used. e 4:1 MeCN: $\mathrm{H}_{2} \mathrm{O}$ was used. ${ }^{\mathrm{f}} \mathrm{A}$ mixture 8:1:1 of MeCN:TFE: $\mathrm{H}_{2} \mathrm{O}$ was used as solvent.

Based on the criteria of yield and enantioselectivity, it was decided to employ conditions of $0.1 \mathrm{~mol} \%$ catalyst loading of iodine $3,-5{ }^{\circ} \mathrm{C}$ reaction temperature and amounts of terminal oxidant of 1.8 and 2.2 equivalents (method $\mathrm{A}$ and $\mathrm{B}$, 
respectively). Under the two optimized protocols, the reaction is general for a range of phenols. Table 2 displays 9 examples of different phenols $\mathbf{5 a - h}$ that could be converted into the corresponding dearomatized para-quinol products $\mathbf{6 a - h}$ in an enantioselective manner.

In general, the 2,4-disubstitution pattern allows for a reasonable enantioselective induction as demonstrated for compounds 5af. Steric size of the 2-substitutent does not effect the enantioselectivities to any major extent (Me in $\mathbf{6 a}$ vs. $t \mathrm{Bu}$ in $\mathbf{6 f}$, 50 vs $48 \%$ ee). In contrast to $\mathbf{5 f}$, 2,4-disubstituted substrate $\mathbf{5 g}$ bearing a tert-butyl substituent in the para-position suffers from a significantly decreased reaction rate. Only under conditions $\mathrm{A}$ could a moderate yield of $25 \% \mathbf{6 g}$ be obtained. A related reduced rate was observed for the 3,4-disubstituted phenol $\mathbf{5 h}$, which provided $\mathbf{6 h}$ in $33 \%$ yield and low enantiomeric exces of only $4 \%$. These results suggest that the catalyst 3 preferentially tolerates 2,4-disubstitued phenols 5a-f with variable sunstituent size in the 2-position and a small alkyl substituent in the 4-position.

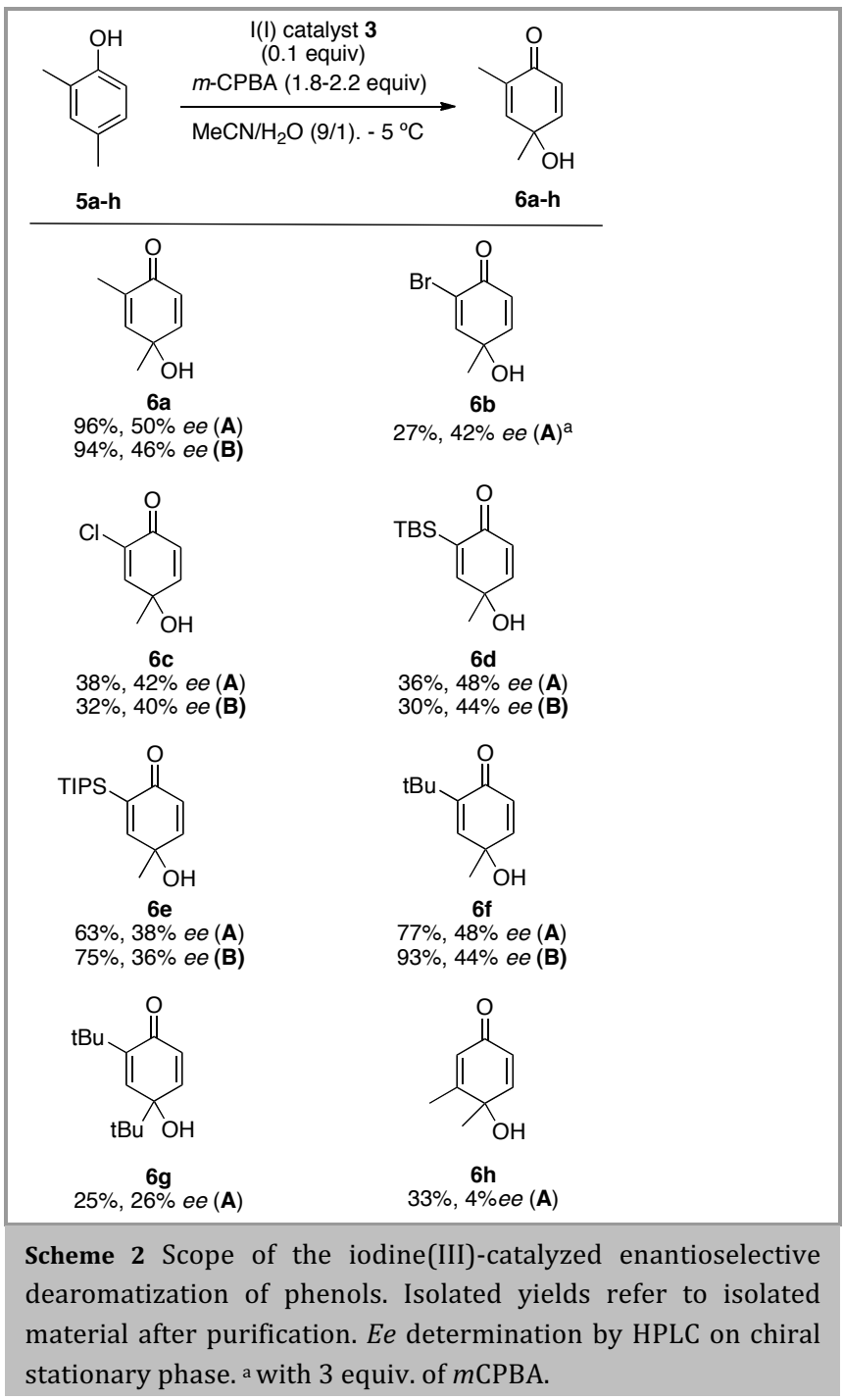

The mechanistic context for this intermolecular enantioselective iodine(I/III)-catalyzed dearomatization reaction is discussed in Figure 2. The catalysis initiated with the mCPBA-mediated oxidation of the molecular iodine(I) catalyst to its active
iodine(III) state A. A related catalyst state was recently identified for the corresponding diacetate involved in the diacetoxylation reaction of styrenes.15a Dissociation of one 3chloro benzoate ligand provides a cationic iodine(III) B, which coordinates the phenol within the chiral catalyst pocket. This coordination is based on the steric requirements regarding the 2-, 3- and 4-position of the phenol ring, which were discussed before. It can provide the environment for an efficient differentiation of the prochiral faces of the phenol ring and governs the attack by the water nucleophile within an arrangement C. This postulated transition state for enantioselection is is in excellent agreement with a recent report by Ishihara on related catalyst control through hydrogen bonding in intramolecular 1,2- and 1,4-dearomatization reactions.[12] Upon $\mathrm{C}-\mathrm{O}$ bond formation, the dearomatized product 6 is released together with a molecule of 3-chloro benzoic acid, which regenerates the initial iodine(I) catalyst 3 .

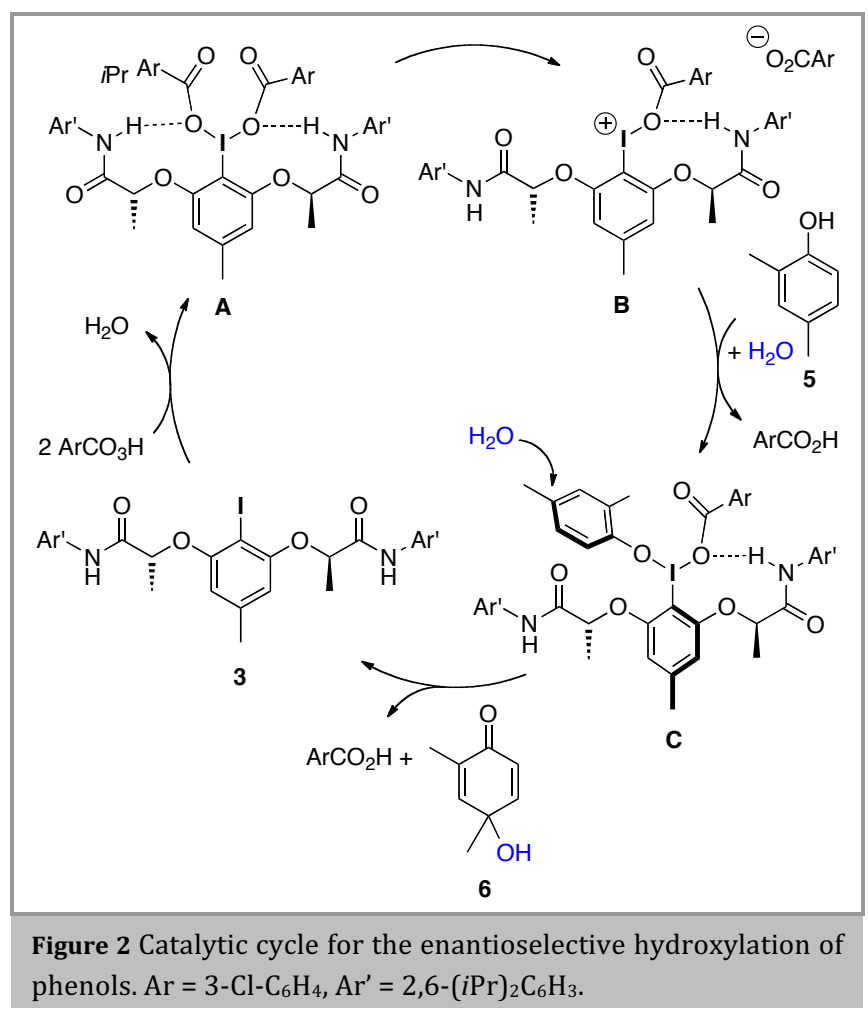

Finally, the reaction scope was extended to the tosylated aniline derivative 7 (Scheme 3). We anticipated that due to an acidity of the $\mathrm{N}-\mathrm{H}$ comparable to the phenol $\mathrm{OH}$ in $\mathbf{5}$ a hydroxylative dearomatization should also be possible. Indeed under the standard conditions, the corresponding imine $\mathbf{8}$ was formed in a completely chemoselective manner. The ee values of $30-34 \%$ for $\mathbf{8}$ compare well with the related compound $\mathbf{6 b}$ and demonstrate that the general selection parameters can be extended from phenols to N-tosyl anilines. A crystal structure of racemic $\mathbf{8}$ was taken to account for its constitution. ${ }^{18}$ Despite repeated attempts, we have so far been unable to grow crystals from the enantiomerically pure batches. 


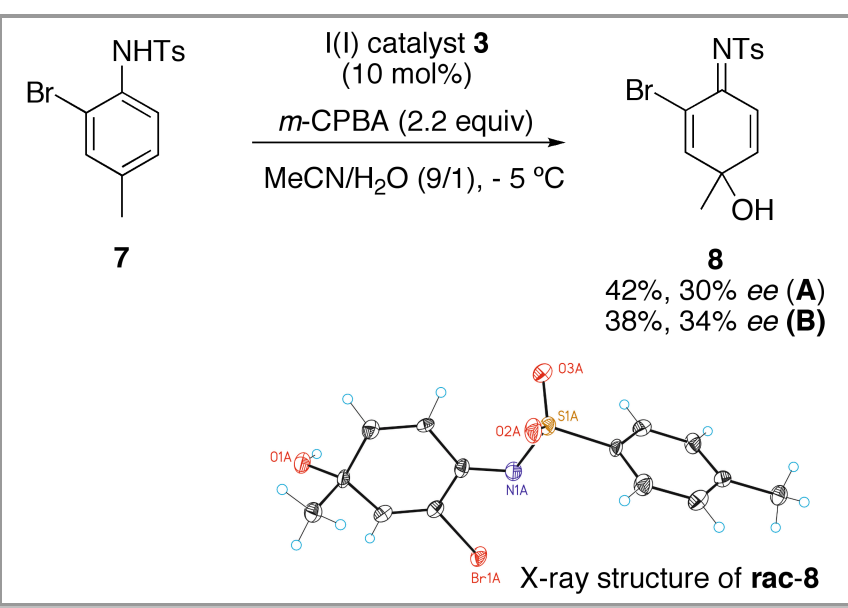

Scheme 3 Iodine(I/III)-catalyzed dearomatization of aniline $\mathbf{7 .}$

In summary, we have developed a second protocol for the iodine(I/III)-catalyzed enantioselective dearomatization of phenols under intermolecular reaction control. The reaction demonstrates that chiral iodine catalysts based on the lactic amide motif can be employed successfully for this kind of reaction

\section{The experimental section has no title; please leave this line here.}

General. All solvents, reagents and all deuterated solvents were purchased from Aldrich and Acros. Column chromatography was performed with silica gel (Merck, type 60, 0.063-0.20 mm). NMR spectra were recorded on a Bruker Avance $300 \mathrm{MHz}, 400 \mathrm{MHz}$ or $500 \mathrm{MHz}$ spectrometer, respectively. All chemical shifts in NMR experiments are reported in ppm downfield from TMS. The following calibrations were used: $\mathrm{CDCl}_{3} \delta=7.26$ and $77.16 \mathrm{ppm}$; DMSO-d $6=2.50$ and $39.52 \mathrm{ppm}$. MS (ESILCMS) experiments were performed using an Agilent 1100 HPLC with a Bruker micro-TOF instrument (ESI). Unless otherwise stated, a Supelco C8 (5 $\mathrm{cm} \times 4.6 \mathrm{~mm}, 5 \mu \mathrm{m}$ particles) column was used with a linear elution gradient from $100 \% \mathrm{H}_{2} \mathrm{O}\left(0.5 \% \mathrm{HCO}_{2} \mathrm{H}\right)$ to $100 \% \mathrm{MeCN}$ in $13 \mathrm{~min}$ at a flow rate of $0.5 \mathrm{~mL} / \mathrm{min}$. MS (EI) and HRMS experiments were performed on a Kratos MS 50 within the service departments at ICIQ. Melting points were determined with a Buchi Melting Point B-540 apparatus. IR spectra were taken with a Bruker Alpha instrument in the solid state. Specific optical rotation values were measured with a Polarimeter JascoP1030 equipped with a $100 \mathrm{~mm}$ cell. HPLC measurements were carried out on a ACQUITY UPLC $®$ system (Waters) UltraPerformance Convergence Chromatography ${ }^{\mathrm{TM}}$ (UPC2 $^{\mathrm{TM}}$ ) equipped with a detector ACQUITY UPLC PDA (Photodiode Array detector). The respective chiral stationary phase and exact conditions are specified for each individual compound within the compound characterization section.

The following compounds were commercially available and used as received 2,4-dimethylphenol (5a), 2-bromo-4-methylphenol (5b), 2chloro-4-methylphenol (5c), 2-(tert-butyl)-4-methylphenol (5f), 2,4-ditert-butylphenol $\quad(\mathbf{5 g}), \quad 3,4$-dimethylphenol $\quad(\mathbf{5 h}) . \quad 2$-(tertbutyldimethylsilyl)-4-methylphenol (5d) and 4-methyl-2(triisopropylsilyl)phenol (5e) were synthesized according to a literature protocol. $^{10} \mathrm{~N}$-(2-Bromo-4-methylphenyl)-4-methylbenzenesulfonamide (7) was synthesized according to a literature protocol. ${ }^{17}$ Products $\mathbf{6 a}, \mathbf{b}, \mathbf{c}, \mathbf{d}, \mathbf{e}, \mathbf{h}$ were reported previously. ${ }^{10}$

\section{Procedures}

General Procedures for the enantioselective dearomatization of phenols catalyzed by chiral hypervalent iodine reagent.

Method A: Into a Pyrex tube equipped with a stir bar was placed the respective phenol 5 ( $0.2 \mathrm{mmol}$, 1 equiv), the chiral iodine(I)-compound 3 $(0.02 \mathrm{mmol}, 10 \mathrm{~mol} \%)$ in a mixture of acetonitrile/ $\mathrm{H}_{2} \mathrm{O}(0.16 \mathrm{M}, 9 / 1$ v/v). $m$-CPBA ( $0.44 \mathrm{mmol}, 2.2$ equiv) was added and the mixture was stirred until no further progress was observed. At this point, the reaction was quenched with a saturated aqueous solution of $\mathrm{NaHCO}_{3}(4 \mathrm{~mL})$ and a saturated aqueous solution of $\mathrm{Na}_{2} \mathrm{~S}_{2} \mathrm{O}_{3}(4 \mathrm{~mL})$. The mixture was extracted with $\mathrm{CH}_{2} \mathrm{Cl}_{2}(3 \times 10 \mathrm{~mL})$ and the combined organic phases were dried over $\mathrm{Na}_{2} \mathrm{SO}_{4}$, filtered and concentrated under reduced pressure. The residue was purified by flash column chromatography (silica gel, $n$ hexane/ethyl acetate, 85/15, v/v) to afford the desired quinol 6, which was submitted to HPLC analysis.

Method B: Into a Pyrex tube equipped with a stir bar was placed the respective phenol $\mathbf{5}(0.2 \mathrm{mmol}, 1$ equiv), the chiral iodine(I)-compound 3 $(0.02 \mathrm{mmol}, 10 \mathrm{~mol} \%)$ in a mixture of acetonitrile/trifluoroethanol $/ \mathrm{H}_{2} \mathrm{O}$ $(0.16 \mathrm{M}, 8 / 1 / 1, \mathrm{v} / \mathrm{v} / \mathrm{v})$. Then, $m$-CPBA $(0.36 \mathrm{mmol}, 1.8$ equiv) was added and the mixture was stirred until no further progress was observed. The reaction was quenched with a saturated aqueous solution of $\mathrm{NaHCO}_{3}(4$ $\mathrm{mL}$ ) and a saturated aqueous solution of $\mathrm{Na}_{2} \mathrm{~S}_{2} \mathrm{O}_{3}(4 \mathrm{~mL})$. The layers were separated and the aqueous phase was extracted with $\mathrm{CH}_{2} \mathrm{Cl}_{2}(3 \times 10$ $\mathrm{mL}$ ). The combined organic layers were dried over $\mathrm{Na}_{2} \mathrm{SO}_{4}$, filtered and the solvent was removed under reduced pressure. The crude product was purified by flash column chromatography (silica gel, $n$-hexane/ethyl acetate, $85 / 15, \mathrm{v} / \mathrm{v}$ ) to afford the desired quinol 6 , which was submitted to HPLC analysis.

\section{$\left(2 R, 2^{\prime} R\right)-2,2^{\prime}-((2-I o d o-1,3-p h e n y l e n e) b i s(o x y)) b i s\left(N-\left(\left[1,1^{\prime}-\right.\right.\right.$} biphenyl]-2-yl)propanamide) 4

According to a published procedure, ${ }^{15 a}\left(2 R, 2^{\prime} R\right)$-2,2'-(2-iodo-5-methyl1,3- phenylene)bis(oxy)dipropanoic acid ( $200 \mathrm{mg}, 0.526 \mathrm{mmol}, 1$ equiv), oxalyl chloride (234 mg, $1.841 \mathrm{mmol}, 3.5$ equiv) and a catalytic amount of DMF were stirred in $5 \mathrm{~mL}$ dry DCM for $3 \mathrm{~h}$ at room temperature under an argon atmosphere. The reaction mixture was concentrated under reduced pressure and the crude product together with 2-aminobiphenyl (356 mg, $2.105 \mathrm{mmol}, 4$ equiv) and pyridine $(166 \mathrm{mg}, 2.105 \mathrm{mmol}, 4$ equiv) were stirred in $3 \mathrm{~mL}$ dry DCM for $16 \mathrm{~h}$ at room temperature under an argon atmosphere. The reaction was quenched by addition of aqueous $\mathrm{HCl}(3 \mathrm{M})$. After extraction with DCM, the combined organic phases were dried over anhydrous $\mathrm{Na}_{2} \mathrm{SO}_{4}$ and concentrated under reduced pressure. Purification by flash column chromatography (silica gel, $n$-hexane/ethyl acetate, $80 / 20, v / v$ ) afforded the pure chiral iodine(I)-compound in a (322 mg, 90\%) as a white solid.

m.p.: $65-69^{\circ} \mathrm{C}$.

$[\alpha]_{\mathrm{D}}{ }^{25}:-136.3\left(c=1.00, \mathrm{CHCl}_{3}\right)$.

IR (ATR): $v / \mathrm{cm}^{-1}=3368,1686,1584,1517,1494,1447,1436,1370$, 1303, 1280, 1246, 1090, 1058, 1009.

${ }_{1} \mathrm{H}$ NMR (400 MHz, $\left.\mathbf{C D C l}_{3}\right): \delta / \mathrm{ppm}=8.36(\mathrm{bs}, 2 \mathrm{H}), 8.24(\mathrm{dd}, J=8.3,1.1$ $\mathrm{Hz}, 2 \mathrm{H}$ ), 7.39 (ddd, $J=8.7,7.2,2.0 \mathrm{~Hz}, 2 \mathrm{H}), 7.22-7.30(\mathrm{~m}, 14 \mathrm{H}), 7.15(\mathrm{t}, J=$ $8.3 \mathrm{~Hz}, 1 \mathrm{H}), 6.39(\mathrm{~d}, J=8.3 \mathrm{~Hz}, 2 \mathrm{H}), 4.76(\mathrm{q}, J=6.7 \mathrm{~Hz}, 2 \mathrm{H}), 1.65(\mathrm{~d}, J=6.7$ $\mathrm{Hz}, 6 \mathrm{H})$.

${ }^{13} \mathrm{C}$ NMR (100 MHz, $\left.\mathbf{C D C l}_{3}\right): \delta=169.6,156.9,138.0,134.0,133.6,130.5$, 130.1, 129.3, 129.1, 128.4, 128.1, 125.2, 122.3, 107.0, 80.8, 76.5, 18.9.

HRMS (ESI-MS): calcd. for $\mathrm{C}_{36} \mathrm{H}_{31} \mathrm{IN}_{2} \mathrm{NaO}_{4}$ : 705.1221, found: 705.1220.

4-Hydroxy-2,4-dimethylcyclohexa-2,5-dienone (6a): Isolated yield: Method A: $26.5 \mathrm{mg}(96 \%)$, Method B: $26 \mathrm{mg}$ (94\%). HPLC-conditions for the quinol: $\mathrm{IA}, \mathrm{CO}_{2}: \mathrm{PrOH}=95: 5,1500 \mathrm{psi}, 3 \mathrm{~mL} / \mathrm{min}, t_{\mathrm{R}}=1.80$ (minor), 2.33 (major), Method A: 50\% ee, Method B: 46\% ee.

2-Bromo-4-hydroxy-4-methylcyclohexa-2,5-dienone (6b): Isolated yield: $11 \mathrm{mg}(27 \%)$. HPLC-conditions for the quinol: $\mathrm{IA}, \mathrm{CO}_{2}: \mathrm{MeOH}=$ 90:10, $1500 \mathrm{psi}, 3 \mathrm{~mL} / \mathrm{min}, t_{\mathrm{R}}=1.56$ (major), 1.88 (minor): $42 \%$ ee.

2-Chloro-4-hydroxy-4-methylcyclohexa-2,5-dienone (6c): Isolated yield: Method A: $12 \mathrm{mg}(38 \%)$, Method B: $10 \mathrm{mg}$ (32\%). HPLC-conditions for the quinol: $\mathrm{IA}, \mathrm{CO}_{2}: \mathrm{EtOH}=90: 10,1500 \mathrm{psi}, 3 \mathrm{~mL} / \mathrm{min}, t_{\mathrm{R}}=1.38$ (major), 1.93 (minor), Method A: 42\% ee, Method B: 40\% ee.

2-(tert-Butyldimethylsilyl)-4-hydroxy-4-methylcyclohexa-2,5dienone (6d): Isolated yield: Method A: $17 \mathrm{mg}$ (36\%), Method B: 14.1 $\mathrm{mg}(30 \%)$. HPLC-conditions for the quinol: $\mathrm{IC}_{\mathrm{C}} \mathrm{CO}_{2}: \mathrm{MeOH}=98: 2,1500$ psi, $3 \mathrm{~mL} / \mathrm{min}, t_{\mathrm{R}}=2.90$ (minor), 4.90 (major), Method A: $48 \% e e$, Method B: 44\% ee.

4-Hydroxy-4-methyl-2-(triisopropylsilyl)cyclohexa-2,5-dienone (6e): Isolated yield: Method A: $35 \mathrm{mg}$ (63\%), Method B: $42.2 \mathrm{mg}(75 \%)$. HPLC-conditions for the quinol: IC, $\mathrm{CO}_{2}: \mathrm{PrOH}=90: 10,1500 \mathrm{psi}, 3$ 
$\mathrm{mL} / \mathrm{min}, t_{\mathrm{R}}=2.89$ (minor), 3.62 (major), Method A: 38\% ee, Method B: $36 \%$ ee.

4-Hydroxy-3,4-dimethylcyclohexa-2,5-dienone (6f): Isolated yield: Method A: $9 \mathrm{mg}(33 \%)$. HPLC-conditions for the quinol: $\mathrm{IA}, \mathrm{CO}_{2}: \mathrm{PrOH}=$ 95:5, $1500 \mathrm{psi}, 3 \mathrm{~mL} / \mathrm{min}, t_{\mathrm{R}}=3.33$ (minor), 3.77 (major), Method A: 4\% ee.

\section{2-(tert-Butyl)-4-hydroxy-4-methylcyclohexa-2,5-dienone (6f)}

Synthesized according to the general procedures. Yellow solid. Isolated yield: Method A: $28 \mathrm{mg}$ (77\%), Method B: $33.5 \mathrm{mg}(93 \%)$

m.p.: $92-94^{\circ} \mathrm{C}$

IR (ATR): $v / \mathrm{cm}^{-1}=3368,2993,2952,2868,1663,1615,1487,1457$ 1386, 1366, 1264, 1138, 1121, 1052, 1012, 935, 902, 866, 843.

${ }^{1} \mathbf{H}-N M R\left(300\right.$ MHz $\left.\mathbf{C D C l}_{3}\right): \delta / \mathrm{ppm}=6.75(\mathrm{dd}, \mathrm{J}=9.8,3.0 \mathrm{~Hz}, 1 \mathrm{H}), 6.63$ (d, J = 3.0 Hz, 1H), 5.98 (d, J = 9.8 Hz, 1H), 2.67 (bs, 1H), $1.42(\mathrm{~s}, 3 \mathrm{H}), 1.18$ (s, 9H).

${ }^{13}$ C-NMR (75 MHz, $\mathbf{C D C l}_{3}$ ): $\delta / \mathrm{ppm}=185.8,150.0,146.0,144.2,128.8$, 67.8, 34.4, 29.2, 27.4 .

HRMS (ESI): calcd for $\mathrm{C}_{11} \mathrm{H}_{15} \mathrm{O}_{2}$ : 179.1078 , found: 179.1080 .

HPLC-conditions: IE, $\mathrm{CO}_{2}: \mathrm{MeOH}=98: 2,2000 \mathrm{psi}, 3 \mathrm{~mL} / \mathrm{min}, t_{\mathrm{R}}=2.10$ (minor), 3.35 (major), Method A: 48\% ee, Method B: 44\% ee.

\section{2,4-Di-tert-butyl-4-hydroxycyclohexa-2,5-dienone (6g)}

Synthesized according to the general procedure (Method A). Yellow solid. Isolated yield: $11 \mathrm{mg}$ (25\%).

m.p.: $65-66^{\circ} \mathrm{C}$

IR (ATR): $v / \mathrm{cm}^{-1}=3415,2957,2909,2870,1660,1623,1481,1461$, $1390,1360,1203,990,958,846$.

1H-NMR (500 MHz, $\mathbf{C D C l}_{3}$ ): $\delta / \mathrm{ppm}=6.83(\mathrm{dd}, J=10.1,3.1 \mathrm{~Hz}, 1 \mathrm{H}), 6.72$ (d, $J=3.1 \mathrm{~Hz}, 1 \mathrm{H}), 6.10$ (d, $J=10.1 \mathrm{~Hz}, 1 \mathrm{H}), 2.21$ (bs, 1H), $1.21(\mathrm{~s}, 9 \mathrm{H})$, $0.99(\mathrm{~s}, 9 \mathrm{H})$.

${ }^{13}$ C-NMR (126 MHz, $\mathbf{C D C l}_{3}$ ): $\delta / \mathrm{ppm}=185.6,148.0,146.2,143.9,130.7$, $74.3,39.3,34.8,29.3,25.5$.

HRMS (ESI): calcd for $\mathrm{C}_{14} \mathrm{H}_{21} \mathrm{O}_{2}: 221.1547$, found: 221.1552 .

HPLC-conditions: IC, $\mathrm{CO}_{2}:{ }^{\mathrm{P} O \mathrm{Pr}}=90: 10,1500 \mathrm{psi}, 3 \mathrm{~mL} / \mathrm{min}, t_{\mathrm{R}}=0.96$ (minor), 1.67 (major), Method A: 26\% ee.

$N$-(2-bromo-4-hydroxy-4-methylcyclohexa-2,5-dien-1-ylidene)-4methylbenzenesulfonamide (8)

Synthesized according to the general procedures. White solid. Isolated yield: Method A: $30 \mathrm{mg}$ (42\%), Method B: $28 \mathrm{mg}$ (38\%)

m.p.: $141-142^{\circ} \mathrm{C}$

IR (ATR): $v / \mathrm{cm}^{-1}=3414,3029,2983,2923,1739,1636,1582,1539$, $1441,1364,1301,1241,1137,1083,1043,870,812$.

${ }^{1} \mathbf{H}-N M R\left(400 \mathbf{~ M H z} \mathbf{C D C l}_{3}\right): \delta / \mathrm{ppm}=7.91(\mathrm{~d}, J=8.3 \mathrm{~Hz}, 1 \mathrm{H}), 7.44(\mathrm{~d}, J=$ $10.1 \mathrm{~Hz}, 1 \mathrm{H}), 7.37-7.30(\mathrm{~m}, 1 \mathrm{H}), 7.24(\mathrm{~d}, J=2.5 \mathrm{~Hz}, 1 \mathrm{H}), 6.84(\mathrm{dd}, J=10.1$, $2.5 \mathrm{~Hz}, 1 \mathrm{H}), 2.44$ (s, 3H), 2.42 (bs, 1H), 1.48 (s, 3H).

${ }^{13}$ C-NMR (101 MHz, $\mathbf{C D C l}_{3}$ ): $\delta / \mathrm{ppm}=160.0,152.5,151.1,144.1,138.2$, $129.7,127.2,122.0,119.9,69.9,26.3,21.8$

HRMS (ESI-MS): calcd for $\mathrm{C}_{14} \mathrm{H}_{13} \mathrm{BrNO}_{3} \mathrm{~S}: 353.9805$, found: 353.9797 .

HPLC-conditions: IC, $\mathrm{CO}_{2}: \mathrm{EtOH}=85: 15,1500 \mathrm{psi}, 3 \mathrm{~mL} / \mathrm{min}, t_{\mathrm{R}}=2.00$ (major), 2.50 (minor). Method A: 30\% ee, Method B: 34\% ee.

\section{Acknowledgment}

Financial support for this project was provided from the Spanish Ministry for Economy and Competitiveness and FEDER (CTQ2014-25027 grant to K. M., and Severo Ochoa Excellence Accreditation 2014-2018 to ICIQ, SEV-2013-0319), and the Government of Catalonia. The authors thank Simona Curreli and the chromatography unit at ICIQ for HPLC analyses.

\section{Supporting Information}

Supporting Information is provided as pdf and contains reproduction of ${ }^{1} \mathrm{H}$ and ${ }^{13} \mathrm{C}$ spectra of new products.

\section{Primary Data}

No.

\section{References}

(1) (a) Zhdankin, V. V. Hypervalent Iodine Chemistry. Preparation, Structure and Synthetic Applications of Polyvalent Iodine Compounds, Wiley: Chichester, 2013. (b) Stang, P. J.; Zhdankin, V. V. Chem. Rev. 1996, 96, 1123. (c) Zhdankin, V. V.; Stang, P. J. Chem. Rev. 2002, 102, 2523. (d) Zhdankin, V. V.; Stang, P. J. Chem. Rev. 2008, 108, 5299.

(2) (a) Richardson, R. D.; Wirth, T. Angew. Chem. Int. Ed. 2006, 45, 4402. (b) Ochiai, M.; Miyamoto, K. Eur. J. Org. Chem. 2008, 4229. (c) Ochiai, M. Chem. Rec. 2007, 7, 12. (d) Dohi, T.; Kita, Y. Chem. Commun. 2009, 2073. (e) Uyanik, M.; Ishihara, K. Chem. Commun. 2009, 2086.

(3) (a) Kita, Y.; Dohi, T. Chem. Rec. 2015, 15, 886. (b) Pouységu, L.; Sylla, T.; Garnier, T.; Rojas, L. B.; Charris, J.; Deffieux, D.; Quideau, S. Tetrahedron 2010, 66, 5908. (c) Quideau, S.; Pouységu, L.; Peixoto, P. A.; Deffieux, D. in Hypervalent Iodine Chemistry (Ed. Wirth, T.), Top. Curr. Chem. Vol. 373, Springer: Stuttgart, 2016, pp. 25-74. (d) Uyanik, M.; Ishihara, K. in Asymmetric Dearomatization Reactions (Ed.: You, S.-L.), Wiley-VCH: Weinheim, 2016, pp. 129 152.

(4) (a) Yakura, T.; Konishi, T. Synlett 2007, 765. (b) Yakura, T.; Tian, Y.; Yamauchi, Y.; Omoto, M.; Konishi, T. Chem. Pharm. Bull. 2009, 57, 252. (c) Yakura, T.; Omoto, M. Chem. Pharm. Bull. 2009, 57, 643. (d) Yakura, T.; Omoto, M.; Yamauchi, Y.; Tian, Y.; Ozono, A. Tetrahedron 2010, 66, 5833.

(5) Uyanik, M.; Mutsuga, T.; Ishihara, K. Angew. Chem. 2017, 129, DOI: 10.1002/ange.201612463; Angew. Chem. Int. Ed. 2017, 56, DOI: 10.1002/anie.201612463.

(6) Uyanik, M.; Mutsuga, T.; Ishihara, K. Molecules 2012, 17, 8604.

(7) For reviews on enantioselective iodine(III) catalysis: (a) Uyanik, M.; Ishihara, K. J. Synth. Org. Chem. Jpn. 2012, 70, 1116. (b) Singh, F. V.; Wirth, T. Chem. Asian J. 2014, 9, 950. (c) Romero, R. M.; Wöste, T. H.; Muñiz, K. Chem. Asian J. 2014, 9, 972. (d) Berthiol, F. Synthesis 2015, 47, 587. (e) Liang, H.; Ciufolini M. A. Angew. Chem. 2011, 123, 12051; Angew. Chem. Int. Ed. 2011, 50, 11849.

(8) Harned, A. M. Tetrahedron Lett. 2014, 55, 4681.

(9) Quideau, S.; Lyvinec, G.; Marguerit, M.; Bathany, K.; OzanneBeaudenon, A.; Buffeteau, T.; Cavagnat, D.; Chénedé, A. Angew. Chem. 2009, 121, 4675; Angew. Chem. Int. Ed. 2009, 48, 4605.

(10) Volp, K. A.; Harned, A. M. Chem. Commun. 2013, 49, 3001.

(11) (a) Dohi, T.; Maruyama, A.; Yoshimura, M.; Morimoto, K.; Tohma, H.; Kita, Y. Angew. Chem. 2005, 117, 6349; Angew. Chem. Int. Ed. 2005, 44, 6193. (b) Dohi, T.; Maruyama, A.; Minamitsuji, Y.; Takenaga, N.; Kita, Y. Chem. Commun. 2007, 43, 1224. (c) Dohi, T.; Takenaga, N.; Fukushima, K.; Uchiyama, T.; Kato, D.; Shiro, M.; Fujioka, H.; Kita, Y. Chem. Commun. 2010, 46, 7697. (d) Ngatimin, M.; Frey, R.; Andrews, C.; Lupton, D. W.; Hutt, O. E. Chem. Commun. 2011, 47, 11778.

(12) Uyanik, M.; Sasakura, N.; Mizuno, M.; Ishihara, K. ACS Catal. 2017, 7,872 .

(13) (a) Dohi, T.; Maruyama, A.; Takenaga, N.; Senami, K.; Minamitsuji, Y.; Fujioka, H.; Caemmerer, S. B.; Kita, Y. Angew. Chem. 2008, 120, 3847; Angew. Chem. Int. Ed. 2008, 47, 3787. (b) Uyanik, M.; Yasui, T.; Ishihara, K. Tetrahedron 2010, 66, 5841. (c) Uyanik, M.; Yasui, T.; Ishihara, K. Angew. Chem. 2010, 122, 2221; Angew. Chem. Int. Ed. 2010, 49, 2175. (d) Uyanik, M.; Yasui, T.; Ishihara, K. Angew. Chem. 2013, 125, 9385; Angew. Chem. Int. Ed. 2013, 52, 9215. (e) Dohi, T.; Takenaga, N.; Nakae, T.; Toyoda, Y.; Yamasaki, M.; Shiro, M.; Fujioka, H.; Maruyama, A.; Kita, Y. J. Am. Chem. Soc. 2013, 135, 4558.

(14) (a) Pouységu, L.; Marguerit, M.; Gagnepain, J.; Lyvinec, G.; Eatherton, A. J.; Quideau, S. Org. Lett. 2008, 10, 5211. (b) Lebrasseur, N.; Gagnepain, J.; Ozanne-Beaudenon, A.; Léger, J.M.; Quideau, S. J. Org. Chem. 2007, 72, 6280. (c) Gagnepain, J.; Castet, F.; Quideau, S. Angew. Chem. Int. Ed. 2007, 46, 1533; Angew. Chem. 
Int. Ed. 2008, 47, 628. For application of the corresponding amination-dearomatization, see: (d) Liang, H.; Ciufolini, M. A. Tetrahedron 2010, 66, 5884. (e) Kasahara, T.;Ciufolini, M. A. Can. J. Chem. 2013, 91, 82. (f) Paladino, M., Zaifman, J.; Ciufolini, M. A. Org. Lett. 2015, 17, 3422 .

(15) (a) Haubenreisser, S.; Wöste, T. H.; Martínez, C.; Ishihara, K.; Muñiz, K. Angew. Chem. 2016, 128, 422, Angew. Chem. Int. Ed. 2016, 55, 413. (b) Wöste, T. H.; Muñiz, K. Synthesis 2016, 48, 816.

(16) For related contributions: (a) Molnár, I. G.; Gilmour, R. J. Am. Chem. Soc. 2016, 138, 5004. (b) Banik, S. M.; Medley, J. W.;
Jacobsen, E. N. J. Am. Chem. Soc. 2016, 138, 5000. (c) Banik, S. M.; Medley, J. W.; Jacobsen, E. N. Science 2016, 353, 51.

(17) Song, H.; Liu, Y.; Liu, Y.; Wang, Q. Org. Lett. 2014, 16, 3240.

(18) Details on the crystal structure analyses of compounds $\mathbf{5 c}$, $\mathbf{d}$ were deposited with the Cambridge Crystallographic Data Centre (CCDC). They can be obtained from the CCDC citing the following numbers: CCDC 1542367. 